\title{
'Free Trade' and the Varieties of Eighteenth-Century State Competition
}

James Stafford

The ideology of free trade is commonly associated with an idea of the peaceful interdependence of states and peoples. Eighteenth-century philosophers such as Montesquieu and Immanuel Kant believed that growing commerce between European states could (at the least) set limits to the duration and intensity of modern wars (Hirschman 2013). In the nineteenth century, free trade was associated with a normatively charged, civilizational rhetoric of human progress-one that provided a justification for the violent opening of China and Japan to British, American and French goods and merchants (Todd 2008). Liberal and neoliberal narratives of the twentieth century collapse of this European civilization, meanwhile, attribute significant blame to the failure to rebuild an open and coherent trading system in the aftermath of the First World War (Link 2018).

This understanding of the history of free trade emphasizes the distinction it draws between price competition within global markets for goods and services-involving firms, workers and consumers-and the political rivalries of trading states (Neff 1990). The maintenance of this distinction between state and market competition lies at the heart of modern organs of liberal economic governance, such as the European Union (Patel and Schweitzer 2013) and the World Trade Organization (Howse 2016). As a reading of the political character and historical origins of a policy of 'free trade', however, is at best partial. By drawing a line from the French doux commerce thesis of the eighteenth century through the pax Britannica of the nineteenth and the 'rules-based order' of the post-war period, it misses out a crucial chapter in the origin story of 'free trade'. This is the distinct case made by a range of British intellectuals and merchants for a transformation of the imperial "fiscal-military state" (Brewer 1989) during its late eighteenth-century apotheosis. 
During this period, the case for 'free trade' in Britain was not articulated as a "vision of global order" (Howe 2007). It was not yet linked to either the bleak verities of Evangelical Christianity (Hilton 1988), nor the expansive cosmopolitanism of the Manchester manufacturer Richard Cobden and the AntiCorn Law League of the 1840s (Howe 1998). Instead, free trade was discussed as a strategy for imperial fiscal reform, aimed at securing Britain's prosperity and security against its main imperial rival: Bourbon France. Far from seeking to insulate market competition from state competition-still less, as Cobden and his allies would later demand, to effectively replace the latter with the former-eighteenth-century British advocates for 'free trade' claimed that opening and integrating the markets of the British Empire could enable it to more durably sustain the costs of its security and expansion.

A policy of free trade would lower the cost of food and raw materials, maximize tax revenue and increase export competitiveness, improving productivity and driving the efficient allocation of scarce capital. It would remove the inefficiencies and distortions created by what the famous eighteenth-century advocate for 'free trade', the Scottish jurist and moral philosopher Adam Smith, called Britain's "mercantile system" (Smith 1976a: IV.I.1). Most of all, it would limit the growing danger of imperial and military and over-reach, generated by the pathological insistence of powerful mercantile lobbies on the necessity for wars of colonial conquest. Unlike their nineteenth-century successors, eighteenth-century British free traders argued against these wars on grounds of prudence, not morality. "Going to war for the sake of trade" (Tucker 1776: 59) ultimately served only to increase the profits of merchants and war contractors, and forced successive British government to expand the national debt to a degree that would fatally undermine the commercial prosperity of the empire. Yet the threat of France remained real, and war was always to be expected. 'Free Trade' was allied to a policy of strategic restraint and even neutrality, rather than a cosmopolitan vision of the British empire as an indispensable agent of peace and human progress.

The idea that the "cosmopolitical economics" of free trade were ultimately self-serving was most famously articulated by the German economist Friedrich List and his US-American followers in the nineteenth century (Palen 2016; see also Nagel/Werron in this volume). Britain, these charged, had only adopted a policy of free trade once its dominance of global markets had been assured through unrestrained naval warfare, protectionism, and colonial exploitation; all of which enabled Britain to build up overwhelming manufacturing and shipping capacity that no other power could match. 
List's argument remains a topic of lively debate among historians of Britain's 'Industrial Revolution' (Ashworth 2017; Mokyr 2009). Yet it serves further to highlight the under-rated distinctiveness of the case made for free trade before victory in the Napoleonic wars secured the British Empire's nineteenthcentury political-economic hegemony. Before it was the hypocritical doctrine of a global empire built through protection, slavery and military conquest, 'free trade' was understood as an alternative path to power, as well as a means of slowing (if not eliminating) the very cycle of global colonial and commercial rivalry that would ultimately deliver Britain to its commanding position in nineteenth-century world politics.

The present contribution seeks to reconstruct this distinctive perspective on the logics of political and commercial competition in the eighteenth-century European world in the decades before the French Revolution. Alongside Smith, it focuses on a lesser-known economic thinker, the Anglo-Dutch merchant and financier Matthew Decker. Both Smith and Decker made distinct arguments for free trade as the solution to the political and commercial challenges facing the British empire in the era of the War of the Austrian Succession (1740-48), the Seven Years' War (1756-63) and the War of American Independence (1776-1783). Smith is more usually credited as the intellectual progenitor of Britain's nineteenth-century turn to free trade. Yet, as the following will show, it was Decker's expansive vision of Britain as a giant 'Free Port' that most clearly anticipated the fiscal and naval politics of the nineteenth-century empire.

The next section outlines the global political and economic context for the Franco-British confrontation of the eighteenth century, and the nature of contemporary British ambitions for an 'empire of the seas' that could check French ambition on land. Inter-imperial rivalry was reflected by a conscious process of emulation in the design of policies and institutions, with the emergent 'science' of commerce at its center (Adelman 2015; Reinert 2011). In this context, it was unthinkable to pursue 'free trade' as a strategy of cosmopolitan benevolence. The case for a radical reform of the British imperial system necessarily rested on the argument that free trade would ultimately enable the empire to better secure its competitive position in relation to its French rival.

The subsequent two sections deal with two contrasting variants of free trade strategy in eighteenth-century Britain. Matthew Decker advanced a case for free trade that rested on Britain's unique ability to dominate European and colonial shipping networks through the abolition of the seventeenth-century 
'Navigation Acts' that restricted access to British and imperial ports to ships carrying the flag of Great Britain. Adam Smith, by contrast, argued for the preservation of the Acts as a vital bulwark of imperial security. Behind the wooden walls of a British navy sustained by a national shipping monopoly, the gradual removal of duties and prohibitions and the integration of the imperial fiscal state would enable an explosion of manufacturing productivity and export competitiveness. The resultant tax revenues would save the empire from its nemesis: the public debt that had built up over decades of unnecessary wars of colonial aggression.

The fourth and final section considers what this historical reconstruction of what we might think of as a 'realist'-even nationalist - variant of free trade has to tell us about the relationship between state and market competition in a multipolar global political economy. Contemporary observers present at the inception of economic liberalism in eighteenth-century Britain well understood that 'free trade', while opening the possibility to positive-sum exchanges among market actors residing in different polities, meant a reconfiguration, not an abandonment, of pre-existing patterns of political competition between the European powers. While this involved a retreat from direct military conflict, it also intensified the pressure of economic competition, rendering productivity and social discipline under open market conditions the indispensable condition of national security.

\section{The Competitive Conjuncture of the Eighteenth Century}

Political and economic relations in eighteenth-century Europe was defined by the coexistence of significant commercial expansion with an escalating cycle of global military conflict. These two circumstances were connected at a fundamental level by the challenges of financing expanding and modernized armed forces, which were in turn required to defend the sources of revenue that guaranteed rival powers' ability to triumph in future wars. From the Nine Years' War of 1689-97 to the French Revolutionary and Napoleonic Wars of 1789-1815, the 'long eighteenth century' witnessed recurrent warfare that spread, through the expansion of European colonial and naval power, to South Asia, the Americas and the Caribbean (Baugh 2011). While less catastrophic in their regional effects than the seventeenth century's wars of religion, the eighteenth century's conflicts over the European 'balance of power' 
were more far-reaching in their consequences for a global conjuncture defined by the consolidation of wealth and military force in Western Europe.

The entanglement of European power-politics with colonial expansion was driven by the circumstances of what the historian Christopher Bayly has termed "archaic globalization" (Bayly 2004: 52). As recovery from the seventeenth century's "general crisis" (Parker 2017) gathered pace, European elites engaged in the consumption of new commodities acquired through slavery, settler colonialism, and new economic institutions, such as the Dutch and British East India Companies. South American coffee and cocoa, Chinese teas, Caribbean sugar and Indian calicoes became central parts of European material culture. In combination with more locally-routed developments - the expansion of working time (the so-called "industrious revolution" (De Vries 1994)), the rise of scientific, 'improving' agriculture (Jones 2016), and a demographic recovery following the wars and epidemics of the seventeenth century (Alter/Clark 2010: 52-53) - the expansion of longdistance trade in mass 'luxury' goods created a new and more widely diffused sense of prosperity among an emergent bourgeoisie: especially, though not exclusively, in England, France and the Dutch Republic.

It also, however, placed control of colonial trade routes and trading posts at the center of European geopolitical competition. The first major inter-state wars explicitly justified as being in the defense of trading interests-over and above those of confessional or dynastic alignment- were between England and the Dutch Republic in the 1660s (Pincus 1996). By the War of the Spanish Succession (1702-14), English and Dutch opponents of the French King Louis XIV's bid to install his grandson as King of Spain were united in their terror of a 'universal monarchy' (Pincus 1995) that would combine France's landed military might with Spain's control of the slave and bullion trade to South America. "Trade", observed the widely-travelled Scottish mercenary, parliamentarian and pamphleteer Andrew Fletcher in the early years of that conflagration, "is now become the golden ball, for which all nations of the world are contending" (Fletcher 1997: 193).

Why was political control over growing markets in goods and slaves valued so highly in eighteenth-century Europe? Status and prestige were, in the first instance, a crucial factor: a succession of different powers learned to 'emulate' one another's attempts to secure wealth, security and renown through trade and colonization (Adelman 2015). The rise of the Iberian empires in the Americas in the sixteenth century had inspired the first English reflections on the prospects for a limitless "empire of the seas"' (Armitage 2000: 100-124), while 
the rapid rise of the Dutch Republic following its successful revolt against Spain's global mercantile empire inspired emulation of its commercial and financial policies in both France (Isenmann 2017) and England (Jardine 2009).

The value of trade in European politics, however, was far from purely symbolic. It was linked, through the nexus of the gold and silver coinage, to the seventeenth-century "military revolution" (Rogers 2018). New and expensive developments in technologies for shipbuilding, fortification, small arms and artillery demanded that the emergent 'fiscal states' of early modern Europe discover new sources of revenue. These necessarily took the form of gold and silver money acquired through trade on international markets. This was indispensable because it offered a uniquely fungible means of paying troops and sailors in whatever jurisdiction they happened to be serving (Ashworth 2003: 29; Mann 2012: 52-58). Gold and silver were similarly indispensable as an "anchor" for the inter-personal systems of informal credit that underpinned everyday life throughout much of early modern Europe (Muldrew 2001: 84); it was with good reason, therefore, that an influential body of seventeenthcentury English economic thinkers believed metal coinage to be the "blood" of the body politic (Wennerlind 2013). It was in England, too, that a speciebacked system of state debt and paper currency became indispensable to the financing of military conflict, releasing precious gold and silver for use abroad (Dickson 1967).

The centrality of specie currency to war finance and domestic economic growth created a perverse set of incentives for participants in eighteenthcentury European power competition: one that was the object of a growing volume of criticism from philosophers and reformers from the second quarter of the eighteenth century. The security interests and domestic stability of European polities seemed increasingly to depend on their ability to command reliable access to a portion of the global supply of gold and silver. The military conquest and domination of colonies, shipping lanes and trading posts, combined with the pursuit of monopoly control over a limited number of exported goods, was indispensable to securing that access. Yet efforts to maintain and expand that control themselves generated fresh pressures to go in search of new markets, new colonies and new revenues; or at least to prevent rivals from doing the same. The nexus of war finance and foreign trade seemed thus to presage an inescapable, escalating cycle of conflict, in which each war laid the foundations for the next. As the philosopher David Hume complained in 1742, it produced an ambient condition of "jealousy of trade", in which every state 
pursued a "malignant policy" that sought to undermine the prosperity of its neighbors (Hume 1985).

"Jealousy of trade" magnified and altered pre-existing religious, dynastic and national animosities; interdependence, proximity and relative cultural homogeneity expanded, rather than diminishing, the scope for military conflict. "The historic union of the nations of Europe has entangled their rights and interests in a thousand complications," observed the Genevan philosopher Jean-Jacques Rousseau in a despairing commentary on the prospects for peace in Europe, composed at the height of the Seven Years War. "They touch each other at so many points that no one of them can move without giving a jar to all the rest; their variances are all the more deadly, as their ties are more closely woven." (Rousseau 1991: 91).

Given this bleak prospect, thinkers and politicians in eighteenth-century Europe sought, with increasing urgency, to reconceptualize the relationship between commerce and politics: both to help their own polities better understand their true interests, and to think (like Rousseau) at a more systemic level, asking how "jealousy of trade" might be tamed or transcended. These efforts were informed by, and continuous with, a flourishing political-economic literature in every European language, with a lively culture of translation promoting the circulation of key manuals of policy among a growing body of experts in the 'science of commerce' (Reinert 2011).

Without too much oversimplification, we can arrange eighteenth-century projects for the reform of European political economy into two main categories. The first sought to sever permanently the pathological relationship between cash, commerce and war. Advocates of 'perpetual peace'-including the Quaker merchant and North American colonist William Penn, the Saxon philosopher Gottfried Wilhelm Leibniz, the French diplomat the Abbé SaintPierre and (most famously) the Prussian philosopher Immanuel Kant-advocated a transformation of the rules of international conduct, encouraging Europe's states (often, though not always, through a degree of compulsion by a hegemonic power, commonly France) to agree to new systems of international arbitration capable of supplanting military conflict (Stafford 2021). Monetary reformers, such as the Scottish gambler and erstwhile French finance minister John Law (Shovlin 2016), the Irish philosopher George Berkeley (Kelly 1985) and his later eighteenth-century Prussian counterpart Johann Gottlieb Fichte (Nakhimovsky 2011), meanwhile demanded the establishment of national fiat currencies (backed by land, labor, patriotic contributions of plate and jewellery, stocks in trading companies, or a combination of all four) that would 
enable the relative or absolute separation of their respective polities from the vicissitudes of globally circulating metal currencies.

Neither Matthew Decker nor Adam Smith engaged in this kind of utopian speculation. They formed part of a broader mainstream of European thinking on the relationships between war trade: one that sought not to escape the underlying drivers of inter-state competition, but to limit the continued escalation of "jealousy of trade" while continuing to advance the power interests of their own polities. The 'Gournay circle', eighteenth-century French followers of Louis XIV's finance minister Colbert, can be placed in this category (Charles et al. 2011); as can the most influential international jurist of the period, the Neuchâtel diplomat Emmerich de Vattel (Nakhimovsky 2007).

The lesson these thinkers took from the ultimate failure of Louis XIV's efforts to create a 'universal monarchy' in Europe and the Atlantic was that the rise of commerce had rendered wars of conquest too costly to sustain. While war and conquest would not be eliminated through the interdependence created by commerce, their attraction would certainly, over time, be reduced. "Jealousy of trade" might be replaced by a new kind of statecraft fitted to new times: one that sought to preserve a European balance of power through the peaceful expansion of domestic economic capacities, but which did not seek to commit the wealth and armed forces thereby developed to war at the slightest provocation. It is in this light that we should view the interventions made by Decker and Smith in the landscape of British political-economic debate in the third quarter of the eighteenth century, to which we will now turn.

\section{Britain as a 'Free Port': Matthew Decker's Essay on the Causes of the Decline of Foreign Trade (1744)}

Sir Matthew Decker was born to an Amsterdam merchant family in 1679. His fortunes in business and politics followed those of the Dutch Republic: as it gradually ceded commercial and financial pre-eminence to England in the early decades of the eighteenth century, Decker settled in the City of London and was naturalized as an English subject in 1704. During the War of the Spanish Succession, he built up a commanding fortune based on Anglo-Dutch trade while exploiting his political connections to acquire lucrative directorships at the East India and South Sea Companies, alongside (for a time) a seat in Parliament (Gauci 2016). His major intervention in British politicaleconomic debate, An essay on the causes of the decline of the Foreign Trade, and con- 
sequently the value of the lands of Britain (1744; $2^{\text {nd }}$ edn. 1750), occupied a minor but distinguished position in subsequent canons of British free trade: one that justifies its selection as a case-study here. 'There are few if any of the older works on commerce,' wrote the Scottish Ricardian economist James Ramsay McCulloch in 1845, 'that have so many well-founded claims to attention, or that embody so many enlightened, ingenious and original views' (McCulloch 1845: 46).

The reason for McCulloch's retrospective praise is obvious. Decker's Essay advocated the same, or similar, reforms to those demanded by Victorian economic liberals: the abolition of customs duties and the recentering of the tax base on domestic consumption, the opening of British and colonial ports to vessels under any flag, and the abolition of the very monopoly trading companies on whose boards Decker had served. Yet if its prescriptions seemed-with the benefit of McCulloch's supremely confident hindsight- to anticipate the free trade politics of the Victorian era, its context and motivations could not have been more different. Decker's Essay was not concerned, like McCulloch and his contemporaries, with the working-out of incipient class antagonisms within a rapidly industrializing and urbanizing society that faced no serious geopolitical rivals. It offered instead a stark warning about the risks posed to British security by France's successful "cultivation of the arts of peace", and an urgent call to radically reform the British tax system as a means of preserving-and expanding-British naval power (Decker 1750: 156).

The immediate context for Decker's work was the renewal, after a generation of peace, of an intense rivalry between Britain and France. The nature of this rivalry had shifted in emphasis since the seventeenth-century wars waged by Britain and the Dutch republic against Louis XIV's threatened 'universal monarchy'. Whereas in the previous century, England's trading and colonial wealth had been a means of funding a land war against France in the Holy Roman Empire and the Low Countries, confrontation now centered on the high seas: control of lucrative transatlantic trades in sugar and slaves, as well as in contraband with Spain's declining South American empire (Wilson 1988: 77f). The continental 'balance of power' still mattered, but the question of whether to divert scarce resources to the land warfare or to sea defense was increasingly contested in British politics. Foreign and commercial policy was coming under the influence of an emergent 'patriot' faction, hostile to the continental commitment of ministries aligned with the Kingdom's Hanoverian ruling dynasty, but determined to uphold Britain's trading supremacy through an 
aggressive posture in seaborne warfare and colonial conquest (Harris 2002: 115-120).

The naval and mercantile politics of oppositional English 'patriotism' found an echo in Decker's Essay, which closed with a fantasia of British naval dominance that placed 'free trade' at the heart of a revised strategy for containing French power. This provided an apt summary of the British mode of war against a range of European opponents over the subsequent two centuries:

If France can give Laws by Land, Britain can do it by Sea; and in a little time the Sea will command the Land, for our Men of War can destroy their Ships, ravage their Coasts, batter down their Forts, and burn their Sea-Port Towns: this must ruin their Trade, as Trade goes so must their Money, and when the Money is gone the Armies cannot be supported, they must be drawn from the Countries they invade, or they will desert rather than perish with Hunger for want of Pay (Decker 1750: 152-153).

Decker's ambitions for British sea power were commonplace in metropolitan political debate at mid-century. What was an unusual about the Essay was the means proposed to ensure that Britannia did indeed 'rule the waves'. Decker argued that a radical liberalization of British trade would rebound to the benefit of the commercial and naval supremacy his patriotic contemporaries so valued. Britain, he declared, was possessed of "natural advantages" that neither France nor the Dutch republic, "our great Rivals in Trade", could boast. Its island situation and temperate climate, its "mild" form of constitutional monarchy, a "plenty of provisions" that enabled workers to be cheaply fed and ships provisioned, and an abundance of natural resources, alongside a workforce that was naturally "brave, laborious and strong" all but guaranteed the Kingdom's European pre-eminence (Decker 1750: 75-76).

Why, then, as Decker and so many of his contemporaries complained, was British trade "in decline" (Harris 2002: 240-243)? The answer could be found in the heavy taxation and monopolistic policies pursued by successive English and British governments over the past century. Britain's high taxes had acted to raise the prices of the provisions its workers and sailors lived upon (Decker 1750: 10). The consequences were far-reaching, affecting the production, export and re-export of British and colonial goods at every stage (Decker 1750: 18). Monopoly trading companies meanwhile diverted trade from provincial ports to London, adding land transport costs to those required by import and export by sea, and reduced demand for ships and sailors to ply the long 
routes to India, the Ottoman Empire and the South Pacific (Decker 1750: 44). The Navigation Acts-seventeenth-century legislation permitting only British flagged vessels to bring goods to and from British ports-contributed to the high price of provisions and manufactured by limiting the supply of ships serving the country (Decker 1750: 41-42). The restrictions imposed on Irish and colonial exports and shipping left these imperial possessions under-taxed yet impoverished, increasing the burden on British taxpayers: under present policy, Decker lamented, "we drive one part of our People out of Trade by Monopolies, and the other by Taxes" (Decker 1750: 40-41).

The antidote to the British Empire's tottering edifice of taxation and monopoly, Decker urged, was to turn Britain into a "Free Port". What Decker proposed, however, was on a much grander scale than this name suggests, encompassing not just a single city but the entire island of Britain. This was to become a "universal Storehouse", capable of assuming a dominant position in world trade by becoming Europe's most attractive location for merchant capital and the re-export of imported colonial goods. The revenue lost from customs duties would be recouped, Decker argued, through a tax on "luxuries"-coaches, silver plate, jewelry, coffee, wine and chocolate-products which, for Decker, constituted the "bane of Virtue and Industry" (Decker 1750: 17).

In combination, Decker claimed, the abolition of monopolies and customs duties and the introduction of a luxury tax would produce a revolution in British trade. The driver of this transformation would be an expansion of price competition throughout the British economy, enabling the cheapest possible production of goods and the disciplining of excesses of 'luxury' consumption among the mercantile class. Opening British ports and shipping to the cheapest provisions from around the world would mean that "our Labor would be so cheap, that we could send all our Goods to foreign Markets cheaper than any People, by reason of our superior Natural Advantages" (Decker 1750: 105). Imposing a tax on luxuries would remove the burden of customs duties and thereby enable a proliferation of new merchant houses capable of subsisting on lower starting capitals, and who were thus "less liable [...] to combine together to impose on the People extravagant Prices of their Goods" (Decker 1750: 102). It would have the additional effect, moreover, of pushing imported luxury goods back out into the re-export market for other nations to consume, rather than trapping them (and their baneful social effects) within Britain behind walls of customs duties. It was luxury consumption, not luxury trade, 
that was for Decker the most legitimate object of state taxation (Decker 1750: 22-23).

The goal of Decker's proposed suite of radical fiscal reforms was to bring what he termed the "natural advantages" of Britain-its landscape, institutions and laboring people - to the fore, clearing away the artificial distortions of complex taxation and monopoly policies that did nothing but undermine the ultimate goals of British power and security. Decker urged Parliament, instead of legislating explicitly to exclude France from access to British ports and product markets, to construct a fiscal regime capable of maximally extending Britain's ability to build up a commanding merchant marine and a dominant position in export and re-export markets for colonial commodities and domestic manufactures alike. "The certain way to be secure", Decker claimed, "is to be more powerful, that is, to extend our Trade as far as it is capable of; and as Restraints have proved its Ruin, to reject them, and depend on Freedom for Security" (Decker 1750: 151-52).

\section{The Nationalism of Adam Smith's Wealth of Nations (1776)}

Placing Adam Smith's Wealth of Nations (Smith 1976a) a canonical work of political and economic theory, alongside a polemical pièce d'occasion like Decker's Essay may seem like a lopsided comparison. Commonly styled as the 'inventor of modern economics', Smith is associated above all with an ambition to create abstract models of perfectly functioning markets, and with a doctrinal commitment to cosmopolitan 'free trade' as the logical extension of a coldly utilitarian conception of 'economic man'. As generations of scholarship on Smith have now shown, however, Smith's political economy was but a small part of a much larger intellectual project, centered on the moral philosophy of his Theory of Moral Sentiments (Smith 1976b), and above all the legal theory he taught as Professor of Jurisprudence at Glasgow University (Phillipson 2010). The Wealth of Nations was also a profoundly political work, designed at least in part as an intervention in the controversies of its own time, and with a stark message about the kind of polity that was likely to succeed in the highly competitive political and economic juncture of the later eighteenth century (Hont 2005: 1-128).

Over the three decades that separated Smith's Wealth of Nations from Decker's Essay, Britain had triumphed over France in both the War of the Austrian Succession and the Seven Years' War. The latter conflict, however, 
had left the empire perilously overstretched, confronted with the challenges of ruling vast new territories in Canada and India, and panicked by the specter of ever-inflating debts (Elliott 2006: 294-307). The result was a frantic search for new revenues, particularly from the increasingly wealthy North American colonies. The details of the famous dispute over the Westminster Parliament's right to levy taxes on British subjects in North America, which led ultimately to the foundation of the modern United States, lie beyond the scope of this chapter. Instead, we will consider how the central messages of the Wealth of Nations related to the fiscal and imperial predicament of Britain in the 1760 s (when the work was already in preparation) and 1770s, when colonial rebellion and European isolation threatened to end the empire's alltoo rapid rise to global pre-eminence.

The principles of commercial policy outlined in Smith's work can be simply and briefly summarized. There could be no more efficient means of guaranteeing the ability of the nation to defend itself than through the expansion of the productive capacities that would guarantee ready access to the gold, silver and public credit necessary for war fighting when required (Smith 1976b: V.iii.5-8). These, in turn, could only be maximized by extending - as far as was commensurate with political prudence-a "perfect liberty" of domestic and foreign trade, one that would allow the local knowledge and intersubjective social discipline of the autonomous moral agents who made up "commercial society" to direct both labor and "stock" to those places where they would be most profitably employed (Smith 1976b: II.v). Attempts to render the British empire a closed system, obsessed with securing positive balances in gold and silver currency, were hugely damaging to the productive capacity that could alone guarantee both wealth and security. They raised the prices of food and other inputs needed for British manufactures, limited the opportunities for export, and caused the misallocation of capital to long-distance trade and commercial shipping. Worst of all, the military defense of colonial possessions forced the diversion of productive capital into unsustainable war debts (Smith 1976b: V.iii.52-56). If colonies were to be retained, then they needed to accept a simplified and uniform system of taxation, rather than the maze of different prohibitions, subsidies and customs duties that constituted what he termed the "mercantile system" (Smith 1976b: V.iii.69-74). Absent this, it would be better to let them go, and to consider them as colonies on what Smith took to be the 'Greek' model: distinct polities, which could expect little more than an amicable trading relationship with the mother-country (Smith 1976b: IV.vii.a.2). 
Smith's political economy, it should already be apparent, had a distinctly national and European orientation. Where Decker deemed of universal naval domination on the basis of Britain become the "universal storehouse of the world", Smith counselled his readers to focus on domestic and regional trade, and to abandon imperial pretensions. Indeed, he constructed his entire account of European history, contained in the third book of the Wealth of $\mathrm{Na}$ tions, around a sustained criticism of the eighteenth-century European turn to colonization and long-distance trade. This, Smith argued, was the product of an "unnatural and retrograde order" of economic growth (Smith 1976b: III.i.9), one that had long favored the interests of merchants over those of the general population, and those of aristocratic luxury over the parsimony and "prudence" required for productive investment (Smith 1976b: II.iii.19).

Correcting this distortion-a legacy of the fall of Rome and the chaos of the Middle Ages - would be the work of many ages, but it was imperative that Britain stop encouraging it by chasing dreams of global mercantile empire. Britain did not need colonies to supply it with commodities or to sustain its status relative to European rivals-it needed productive, tax-paying artisans and small capitalists, capable of driving the accumulation of wealth on which the state could draw in situations of war and emergency. It should come as little surprise, then, that Smith regarded the ultimate loss of the American colonies with an equanimity that was unusual among his devastated contemporaries. In a 1783 letter to the British minister William Eden, written following the concession of American independence and the conclusion of a humiliating peace treaty with France, Smith speculated that Britain might now be able to "open a commerce with the neighbouring nations of Europe, infinitely more advantageous than that of so distant a country as America" (Smith 1977: 271).

Smith's political judgement on Britain's post-war situation was deeply rooted in the account of the relationship between domestic and foreign trade he had laid out in The Wealth of Nations. Far from envisaging free trade as a global order upheld by Britain, Smith fancied that the abandonment of colonial monopolies and protective tariffs would promote a reorientation of British trade towards the domestic and European markets. Absent the distorting effects of Britain's "mercantile system", Smith reasoned, the owners of capital would be far more inclined to invest it in productive domestic activity than in lengthy and tenuous dealings across the oceans. They could better trust their own countrymen to honour engagements, and better monitor the condition of their goods and money when these were employed closer to 
home. "Every individual endeavours to employ his capital as near home as he can," claimed Smith, "and consequently as much as he can in the support of domestick industry" (Smith 1976a: IV.ii.5-6).

The national bias of capitalists had an important political consequence for Smith-one that drove much of his criticism of a British commercial policy that neglected domestic and European trade for the glittering attractions of Asia and the Americas. Goods bought and sold within the country, Smith reasoned, were capable of supporting twice as much domestic "productive labor" as those involving import and export, where some of the labor supported would be foreign. They would also encourage a far more rapid accumulation of wealth. The greater the distance involved in exchange, Smith argued, the less rapidly the capital of the country, and the fund of productive labor that it could support, would be augmented. Trade between England and Scotland might be twelve times faster than trade between England and Portugal.

Slowest and most "uncertain" of all, however, was the "circuitous" or "carrying trade": the exchange of colonial goods for European, constructed on the principles of the "mercantile system". Seeking to purchase European goods with those imported from the colonies, thereby seeking to protect a fictive 'balance of trade' in gold and silver, was the least efficient means of encouraging the expansion of the country's real productive capacities:

The riches, and so far as power depends upon riches, the power of every country, must always be in proportion to the value of its annual produce, the fund from which all taxes must ultimately be paid. But the great object of the political economy of every country, is to increase the riches and power of that country. It ought, therefore, to give no preference nor superior encouragement to the foreign trade of consumption above the home-trade, nor to the carrying trade above either the other two. It ought neither to force nor to allure into either of those two channels, a greater share of the capital of the country than what would naturally flow into them of its own accord (Smith 1976a: Il.v.31)

Allowing the free play of competition to determine the allocation of British mercantile capital would thereby have the happy effects of reorienting it away from long-distance trade to the Americas and Asia, and towards a more intensive cultivation of domestic agriculture and manufactures. This shift would not be the product of any protective tariff; although Smith, unlike Decker, was prepared to make an exception from the doctrine of "perfect liberty" in the case of the Navigation Acts. These were deleterious to foreign trade, but indis- 
pensable to the maintenance of a merchant marine capable of being turned to the purposes of naval warfare. Since they guaranteed the security of an island nation, the Acts of Navigation were "perhaps the wisest of all the commercial regulations of England" (Smith 1976a: IV.ii.28-30).

Far from being an early exponent Britain's nineteenth-century 'empire of free trade', therefore, Smith prescribed a kind of defensive realism for an overstretched imperial power. The Wealth of Nations offered an argument for a $\mathrm{Eu}$ ropeanized Britain, indifferent (though not actively hostile) to colonial adventures, and relentlessly focused on the expansion of productivity in domestic manufactures and agriculture as the key to its wealth and security. Smith urged his compatriots to abandon their addiction to costly global warfare, in pursuit of far-flung possessions of little or no economic utility. Patient, parsimonious, and cautious in its dealings, the free-trade nation of Smith's imagination would forsake the empire of the seas, and "accommodate her future views and designs to the real mediocrity of her circumstances" (Smith 1976a: V.iii.92).

\section{From 'Jealousy of Trade' to International Competition}

This chapter has sought to disrupt some commonly received notions about the origins of liberal political economy in eighteenth-century Britain. Against a dominant narrative emphasizing the pacific, cosmopolitan and hypocritical character of British arguments for free trade, it has used the examples of Matthew Decker and Adam Smith to suggest that free trade was initially conceptualized as an alternative strategy for British national power and security in the course of its long rivalry with Bourbon France. It has further sought to demonstrate that arguments against what Smith termed "the mercantile system" could have multiple and conflicting political valences. Decker's demands extended to the abolition of Britain's Navigation Acts and aimed at securing dominance of the global carrying trade by transforming the country into a free port. Smith, by contrast, was actively hostile to grand projects of longdistance trade, and the colonial wars that accompanied them. His vision of a Britain governed by the principles of "natural liberty" centered on the abandonment of imperial pretensions, and the intensive cultivation of the domestic agriculture and manufactures that could alone fund national defense for the long term. 
Neither Decker or Smith were able to fully describe or anticipate the interlocking dynamics of military force, capital accumulation and political decision that ultimately rendered Britain the hegemonic power of the nineteenth century. The interest of these texts, however, does not lie in their capacity for prophecy: still less in the success with which they articulate the 'correct' doctrines of latter-day liberal theories of free trade. What is most significant about Decker's Essay and Smith's Wealth of Nations is what connects them: a new conception of the interlocking relationship between economic and political competition, which emerged in the course of the eighteenth-century debate over "jealousy of trade" and remains relevant even under the radically different circumstances of twenty-first century global political economy.

The explicit purpose of Decker and Smith's reconceptualization of Britain's commercial and political interests was to bring about a pause, or reversal, in an unsustainable cycle of military conflict with France. Attempting to 'force' trade into convenient channels through warfare or legislation was a self-defeating strategy that risked ruining the empire. Allowing market competition to reshape the country's trading relationships, by contrast, could unlock new and more durable sources of revenue that would allow Britain to prevail against, or even dominate, its rivals, without having to resort to continuous warfare of the kind that defined the central decades of the eighteenth century. For both Smith and Decker, however, the struggle of arms would ultimately be replaced by the struggle for productivity and social discipline. Maintaining Britain's relative position in the European scale of wealth and power required constant vigilance and adjustment on the part of both capital and labor: it was for this reason that both Decker and Smith were so preoccupied with the destructive influence of luxury consumption on the national character. The abandonment of aggressive naval warfare enabled a dramatic expansion of the reach of a hybrid form of competition, at once political and economic, that involved the entire population in the collective fate of the economic nation. It is this conceptual shift, rather than their contribution to any canon of liberal economic doctrine, that should inspire continued interest in these historic authors.

\section{References}

Adelman, Jeremy (2015): "Mimesis and Rivalry: European Empires and Global Regimes.” In: Journal of Global History 10/1, pp. 77-98. 
Alter, George/Clark, Gregory (2010): "The Demographic Transition and Human Capital." In: Kevin H. O'Rourke/Stephen Broadberry (eds.), The Cambridge Economic History of Modern Europe, Volume 1: 1700-1870, Cambridge: Cambridge University Press, pp. 43-69.

Armitage, David (2000): The Ideological Origins of the British Empire, Cambridge: Cambridge University Press.

Ashworth, William J. (2003): Customs and Excise: Trade, Production, and Consumption in England, 1640-1845, Oxford: Oxford University Press.

Ashworth, William J. (2017): The Industrial Revolution: The State, Knowledge and Global Trade, London: Bloomsbury.

Baugh, Daniel A. (2011): The Global Seven Years' War, 1754-1763: Britain and France in a Great Power Contest, Harlow: Longman.

Bayly, Christopher (2004): The Birth of the Modern World, 1780-1914: Global Connections and Comparisons, Oxford: Blackwell.

Brewer, John (1989): The Sinews of Power: War, Money and the English State, 1688-1783, London: Routledge.

Charles, Loïc/Lefebvre, Frédéric/Théré, Christine (eds.) (2011): Le cercle de Vincent de Gournay: savoirs économiques et pratiques administratives en France au milieu du XVIIIe siècle, Paris: Institut national d'études démographiques.

De Vries, Jan (1994): "The Industrial Revolution and the Industrious Revolution." In: The Journal of Economic History 54/2, pp. 249-270.

Decker, Matthew (1750): An Essay on the Causes of the Decline of the Foreign Trade: Consequently of the Value of the Lands of Britain, and on the Means to Restore Both, London: Printed for J. Brotherton.

Dickson, P. G. M. (1967): The Financial Revolution in England: A Study in the Development of Public Credit, 1688-1756, London: Macmillan.

Elliott, J. H. (2006): Empires of the Atlantic World: Britain and Spain in America, 1492-1830, New Haven: Yale University Press.

Fletcher, Andrew (1997): "An Account of a Conversation." In: John Robertson (ed.), Andrew Fletcher: Political Works, Cambridge: Cambridge University Press, pp. 129-215.

Gauci, Perry (2016): "Decker, Sir Matthew, First Baronet (1679-1749), Political Economist and Merchant." In: Oxford Dictionary of National Biography. Retrieved 1 Feb. 2021, from https://www.oxforddnb.com/view/10.1093/re f:odnb/9780198614128.001.0001/odnb-9780198614128-e-7408.

Harris, Robert (2002): Politics and the Nation: Britain in the Mid-Eighteenth Century, Oxford: Oxford University Press. 
Hilton, Boyd (1988): The Age of Atonement: The Influence of Evangelicalism on Social and Economic Thought, 1795-1865, Oxford: Clarendon Press.

Hirschman, Albert Otto (2013): The Passions and the Interests: Political Arguments for Capitalism before Its Triumph, Princeton: Princeton University Press.

Hont, Istvan (2005): Jealousy of Trade: International Competition and the Nation-State in Historical Perspective, Cambridge, MA: Harvard University Press.

Howe, Anthony (1998): Free Trade and Liberal England 1846-1946, Oxford: Oxford University Press.

Howe, Anthony (2007): "Free Trade and Global Order: The Rise and Fall of a Victorian Vision." In: Duncan Bell (ed.), Victorian Visions of Global Order, Cambridge: Cambridge University Press, 26-46.

Howse, Robert (2016): "The World Trade Organization 20 Years On: Global Governance by Judiciary." In: European Journal of International Law 27/1, pp. 9-77.

Hume, David (1985): "Of the Jealousy of Trade." In: Eugene F. Miller (ed.), Essays Moral Political and Literary, Indianapolis: Liberty Fund, pp. 327-332. Isenmann, Moritz (2017): "Égalité, Réciprocité, Souveraineté: The Role of Commercial Treaties in Colbert's Economic Policy." In: Antonella Alimento/Koen Stapelbroek (eds.), The Politics of Commercial Treaties in the Eighteenth Century: Balance of Power, Balance of Trade, Basingstoke: Palgrave MacMillan, pp. 77-103.

Jardine, Lisa (2009): Going Dutch: How England Plundered Holland's Glory, London: Harper Perennial.

Jones, Peter (2016): Agricultural Enlightenment: Knowledge, Technology and Nature, 1750-1840, Oxford: Oxford University Press.

Kelly, Patrick (1985): "Ireland and the Critique of Merchantilism in Berkeley's 'Querist'." In: Hermathena 139, pp. 101-117.

Link, Stefan (2018): "How Might 21st-Century De-Globalization Unfold? Some Historical Reflections." In: New Global Studies 12/3, pp. 343-365.

Mann, Michael (2012): The Sources of Social Power, Volume I: A History of Power from the Beginning to A.D. 1760, Cambridge: Cambridge University Press.

McCulloch, John Ramsay (1845): The Literature of Political Economy: A Classified Catalogue of Select Publications in the Different Departments of That Science, with Historical, Critical and Biographical Notices, London: Longman, Brown, Green \& Longmans. 
Mokyr, Joel (2009): The Enlightened Economy: An Economic History of Britain, 1700-1850, New Haven: Yale University Press.

Muldrew, Craig (2001): “Hard Food for Midas': Cash and Its Social Value in Early Modern England." In: Past \& Present 170, pp. 78-120.

Nakhimovsky, Isaac (2007): "Vattel's Theory of the International Order: Commerce and the Balance of Power in the Law of Nations." In: History of European Ideas 33/2, pp. 157-173.

Nakhimovsky, Isaac (2011): The Closed Commercial State: Perpetual Peace and Commercial Society from Rousseau to Fichte, Princeton: Princeton University Press.

Neff, Stephen C. (1990): Friends but No Allies: Economic Liberalism and the Law of Nations, New York: Columbia University Press.

Palen, Marc-William (2016): The 'Conspiracy' of Free Trade: The AngloAmerican Struggle over Empire and Economic Globalization, 1846-1896, Cambridge: Cambridge University Press.

Parker, Geoffrey (2017): Global Crisis: War, Climate Change and Catastrophe in the Seventeenth Century, New Haven: Yale University Press.

Patel, Kiran Klaus/Schweitzer, Heike (2013): "Introduction.” In: Kiran Klaus Patel/Heike Schweitzer (eds.), The Historical Foundations of EU Competition Law, Oxford: Oxford University Press, pp. 1-18.

Phillipson, Nicholas T. (2010): Adam Smith: An Enlightened Life, New Haven: Yale University Press.

Pincus, Steven (1995): "The English Debate over Universal Monarchy." In: A Union for Empire: Political Thought and the Union of 1707, Cambridge: Cambridge University Press, pp. 37-62.

Pincus, Steven (1996): Protestantism and Patriotism: Ideologies and the Making of English Foreign Policy, 1650-1668, Cambridge: Cambridge University Press.

Reinert, Sophus (2011): Translating Empire: Emulation and the Origins of Political Economy, Cambridge, MA: Harvard University Press.

Rogers, Clifford J. (ed.) (2018): The Military Revolution Debate: Readings On The Military Transformation Of Early Modern Europe, London: Routledge.

Rousseau, Jean-J. (1991 [1756]) "Abstract and Judgement of Saint-Pierre's Project for Perpetual Peace." In: Rousseau on International Relations, Oxford: Clarendon Press, pp. 53-101.

Shovlin, John (2016): "Jealousy of Credit: John Law's "System" and the Geopolitics of Financial Revolution:" In: The Journal of Modern History 88/2, pp. 275-305. 
Smith, Adam (1976a [1776]): An Inquiry into the Nature and Causes of the Wealth of Nations, Oxford: Clarendon Press.

Smith, Adam (1976b [1791]): The Theory of Moral Sentiments, Indianapolis: Liberty Fund.

Smith, Adam (1977): The Correspondence of Adam Smith. Oxford: Oxford University Press.

Todd, David (2008): "John Bowring and the Global Dissemination of Free Trade." In: The Historical Journal 51/2, pp. 373-97.

Tucker, Josiah (1776): Four Tracts on Political and Commercial Subjects, Gloucester: R. Raikes.

Wennerlind, Carl (2013): "Money: Hartlibian Political Economy and the New Culture of Credit." In: Mercantilism Reimagined: Political Economy in Early Modern Britain and Its Empire, Oxford: Oxford University Press.

Wilson, Kathleen (1988): "Empire, Trade and Popular Politics in MidHanoverian Britain: The Case of Admiral Vernon." In: Past \& Present 121, pp. 74-109. 
